\title{
Pogranicze a polityka bezpieczeństwa
}

Bolesław Sprengel ${ }^{1}$

Link do artykułu:

http://pogranicze.uni.opole.pl/biblioteka/docs/nr1/sprengel_nr1.pdf

Standard cytowania (APA):

Sprengel, B. (2013). Pogranicze a polityka bezpieczeństwa. Pogranicze. Polish Borderlands Studies, $n$ r 1, s. 80.

Od problemów występujących na pograniczu wolne są tylko kraje wyspiarskie, nie mające granic lądowych z innymi państwami. Z badań wynika, że im dłuższa granica i więcej sąsiadów, tym więcej problemów i zagrożeń. Skala problemów wiążących się $\mathrm{z}$ istnieniem pogranicza ma różne podłoże i nie ma bezpośredniego związku z pozycją polityczną kraju. Badania wskazują, że im większe różnice polityczne, ekonomiczne, cywilizacyjne i kulturowe sąsiadujących państw, tym większe napięcia na pograniczu.

Specyficzna sytuacja występuje na pograniczach powstałych w wyniku nowo wyznaczonych granic i przesiedlenia ludności. Polska przez wszystkie wieki posiadania własnego państwa musiała zabiegać o utrzymanie bezpieczeństwa wzdłuż długiej, w większości sztucznej, otwartej i trudnej do ochrony granicy. W przeszłości niechętne władzom polskim obce służby łatwo pozyskiwały, wśród zamieszkujących pogranicza mniejszości narodowych, chętnych do prowadzenia działalności dywersyjnej i wywiadowczej z powodów ideowych lub materialnych, a w ostateczności, uciekając się do szantażu. Na ten ostatni najbardziej podatni byli m.in. przemytnicy.

Po każdej wojnie kończącej się zmianą granicy, polskie (ale nie tylko) władze zmagały się z nielegalnym jej przekraczaniem.
Granica rozdzieliła wiele miejscowości posiadających tradycyjne powiązania ekonomiczne i szlaki komunikacyjne. Najgorzej było tam, gdzie granica rozdzielała gęsto zamieszkałe i posiadające rozwiniętą sieć komunikacyjną osiedla, miasta, wsie, a nawet pojedyncze zagrody. Ludzie tracili miejsca pracy. W wyniku traktatu wersalskiego członkowie wielu rodzin znaleźli się po obu stronach granicy niechętnych, nieprzyjaznych, a czasem nawet wrogich sobie państw. Dotyczyło to zarówno ludności polskiej, jak też mniejszości narodowych. Wiele osób doskonale znało tereny i ludzi mieszkających teraz po drugiej stronie granicy państwa. Wcześniej również tam mieszkali, pracowali, i bywali w celach towarzyskich. Dlatego po wojnie nielegalne przekroczenie granicy i uzyskanie tam pracy lub wsparcia nie stanowiło dla nich problemu.

Współcześni badacze, zwłaszcza socjologowie i pedagodzy, coraz wyraźniej wskazują na interdyscyplinarność problemów pogranicza. Dotyczy to także polityki bezpieczeństwa. Konieczne jest także poszerzenie katalogu pytań, w tym dotyczących polityki państwa i samorządów w celu ograniczenia zjawisk patologicznych i przestępczości na pograniczu oraz zintensyfikowanie studiów nad rozmiarami i dynamiką przestępczości na tych obszarach. \begin{tabular}{l}
\hline 1 Dr hab. Bolesław Sprengel: pracownik Katedry Bezpieczeństwa Wewnętrznego i Międzynarodowego \\
Uniwersytetu Mikołaja Kopernika w Toruniu.
\end{tabular} 